\section{Hypertension control activities in Latin America and the Caribbean: opportunities for late-stage (T4) translation research}

\author{
Luis Alejandro Salicrup, ${ }^{1}$ Pedro \\ Ordunez, ${ }^{2}$ and Michael M. Engelgau ${ }^{3}$
}

Suggested citation Salicrup LA, Ordunez P, Engelgau MM. Hypertension control activities in Latin America and the Caribbean: opportunities for late-stage (T4) translation research. Rev Panam Salud Publica. 2018;42:e22. doi: 10.26633/RPSP.2018.22

\begin{abstract}
This work had two objectives: (1) to identify the extent of the problem and gaps pertaining to hypertension control in Latin America and the Caribbean (LAC) and (2) to identify the potential role for late-stage (T4) translation research to tackle the current and future hypertension burden in that region. We explored the extent of the problem and the potential opportunities to use late-stage (T4) translation research to address it. We analyzed calls to action and policies implemented within several LAC countries and also at the regional level. Some LAC countries are currently developing comprehensive plans for controlling noncommunicable diseases. Additionally, the Pan American Health Organization (PAHO) is working on implementing a comprehensive plan
\end{abstract}

Center for Global Health, National Cancer Institute, National Institutes of Health, Rockville, Maryland, United States of America. Send correspondence to Luis Alejandro Salicrup at salicrupl@paho.org

Pan American Health Organization, Department of Noncommunicable Diseases and Mental Health, Washington, D.C., United States of America.

Center for Translation Research and Implementation Science, National Heart, Lung, and Blood Institute (NHLBI), National Institutes of Health, Bethesda, Maryland, United States of America. of action within the PAHO Strategy for the Prevention and Control of Noncommunicable Diseases. These endeavors underscore the need for and the relevance of implementing effective, evidence-based, affordable interventions for treating and controlling hypertension. In these efforts, late-stage (T4) translation research can help to determine the best strategies for delivery of hypertension control. This latestage (T4) translation research should involve all relevant stakeholders and partners in order to best enhance and scale up appropriate, affordable, and sustainable public health interventions.

Keywords Hypertension; translational medical research; public health; policy; Latin America; West Indies.

Noncommunicable diseases (NCDs) are the leading causes of death globally, killing more people each year than all other causes combined. Contrary to popular opinion, available data demonstrate that nearly $80 \%$ of NCD deaths occur in low- and middle-income countries (LMICs). Despite the rapid growth and inequitable distribution in NCDs, much of the human and social impact caused each year by NCD-related deaths could be averted through well-understood, costeffective, feasible interventions (1).

More people worldwide die from cardiovascular diseases (CVDs) - mainly ischemic heart disease and stroke-than from any other cause (2). Population aging and growth, along with changes in the distribution of risk factors-mostly tobacco use, lack of physical activity, unhealthy diet, and harmful use of alcohol-have accelerated growth in the NCD disease burden within many LMICs (3).

Hypertension is the major contributor to the CVD burden and remains largely undertreated in many LMICs (4). Annually, hypertension is responsible for 7.6 million deaths worldwide (13.5\% of all deaths), more than for any other individual risk factor (4). Approximately $54 \%$ of stroke and $47 \%$ of coronary heart disease in LMICs are attributable to high blood pressure (4). CVD is ranked as the leading cause of death in Latin America and the Caribbean (LAC) $(5,6)$. Every year, an estimated 1.6 million people die from CVD in the Americas, one-third of them before 70 years of age (7).

While hypertension affects between $20 \%$ and $40 \%$ of the adult population in the LAC region, control of hypertension has been prioritized unevenly. Indeed, in 2013, the Prospective Urban Rural Epidemiological Study, which included participants from four LAC

This is an open access article distributed under the terms of the Creative Commons Attribution-NonCommercial-NoDerivs 3.0 IGO License, which permits use, distribution, and reproduction in any medium, provided the original work is properly cited. No modifications or commercial use of this article are permitted. In any reproduction of this article there should not be any suggestion that PAHO or this article endorse any specific organization or products. The use of the PAHO logo is not permitted. This notice should be preserved along with the article's original URL. 
countries (Argentina, Brazil, Chile, Colombia), reported an awareness rate of 57\%; among those aware, a treatment rate of $53 \%$ (with $36 \%$ of those on treatment controlled); and a very low population-level control rate of $19 \%$. All these figures reflect the challenge ahead. The causes for diagnosis, treatment, and control gaps are not completely clear. However, they seem partly due to differences in the level of development and governance of the health system, as well as disparities in access, coverage, and quality of health care services. The LAC region has significant socioeconomic inequalities, and countries are at different stages of economic and social development and organization of their health systems (7).

With hypertension representing a significant disease burden in the LAC region, it is crucial for all regional stakeholders to understand current activities, progress, and challenges for its control. Currently, there are many proven, effective interventions. If they were broadly scaled up, that would improve hypertension control and save millions of lives worldwide (8). However, most of these interventions do not have strategies to initiate, monitor, and sustain their delivery.

This is where late-stage (T4) translation researchresearch that studies optimal and sustainable strategies for delivering proven effective interventionscould tackle this current situation. Late-stage (T4) translation research comes at the end of the biomedical translation research spectrum. That continuum starts with fundamental discovery (T0) and goes on to translation into humans (T1), into patients (T2), and into clinical practice (T3). It concludes with (T4) translation, which takes effective interventions and studies their dissemination and implementation at the population level.

Late-stage (T4) translation research conducts studies in real-world settings, in the context where implementation will actually occur. The results can determine strategies for intervention delivery that are acceptable, affordable, and sustainable (9).

In an effort to address some of the major aspects related to hypertension control in the LAC region, this article focuses on two main objectives: 1) to identify the extent of the problem and the gaps pertaining to hypertension control in the LAC region and 2) to identify the potential role for late-stage (T4) translation research to tackle the current and future hypertension burden in the LAC region.

\section{LATIN AMERICAN AND CARIBBEAN CALLS TO ACTION AND OTHER ACTIVITIES}

In 2012, during the $28^{\text {th }}$ Pan American Sanitary Conference, ministers of health of the Americas endorsed the Pan American Health Organization (PAHO) Strategy for the Prevention and Control of Noncommunicable Diseases (10), along with a Regional Framework for NCD Prevention and
Control. Both of those documents were later further developed in a PAHO publication titled Plan of Action for the Prevention and Control of Noncommunicable Diseases in the Americas 2013-2019 (11). Both the Strategy and the Plan of Action focus on cardiovascular diseases, cancer, diabetes, and chronic respiratory disease, along with four NCD risk factors: tobacco, diet, physical inactivity, and alcohol. The Plan of Action is consistent with the World Health Organization (WHO) Global Action Plan for the Prevention and Control of Noncommunicable Diseases 2013-2020 (12).

In 2012, a PAHO study done in collaboration with the Latin American and Caribbean Center on Health Science Information (BIREME) and other partners reported that among the 35 LAC countries, only 9 had recent representative data on hypertension from national studies (7). This leaves many countries falling short of having the critical information needed to understand trends and establish effective control policies.

The Salt Reduction Initiative in the Americas is focusing on the reformulation of processed foods to reduce their salt content, given that dietary salt intake is a major risk factor for developing hypertension. Started in 2013, this effort is coordinated by PAHO and based on WHO's "best buy" practices. It aims to prevent hypertension and cardiovascular diseases in the Americas (13). Targets and timelines for reduced salt content in processed foods have been developed for six LAC countries: Argentina, Brazil, Chile, Ecuador, Mexico, and Paraguay (14).

Countries in the Americas have NCD prevention and control plans (15) that are aligned with WHO global mandates. What is unique in the LAC region is that more emphasis is being placed on the control of hypertension. This has resulted in the 2019 target for achieving a population-level hypertension control rate of $35 \%$. Meeting that standard will require that roughly $70 \%$ of those with hypertension know their status (awareness), that $70 \%$ of those who know their status are being treated, and that $70 \%$ of those being treated are being controlled (16).

To overcome many issues with hypertension control, PAHO, the U.S. Centers for Disease Control and Prevention (CDC), and other partners launched the Global Standardized Hypertension Treatment Project (GSHTP) in 2014 (17). The aim was to reduce the burden of CVD by developing and implementing standardized pharmacologic treatments for hypertension, thus leading to improved control rates. GSHTP has emphasized three major components: (1) standardized treatment protocols; (2) identification and sustained availability of a core set of affordable and effective hypertension drugs; and (3) registries for clinical tracking and performance evaluation. For the second component of the GSHTP, to improve the availability of drugs, PAHO is playing an important role through the PAHO Strategic Fund, which is an effective mechanism for improving access to and availability of essential medicines for NCDs (18). From 2014 to 2015, 
GSHTP was piloted in Barbados. The results were promising, with increases in blood pressure control rates, development of registries, and improved prescribing practices at primary care levels. In 2016, with technical support from $\mathrm{PAHO}$ and in collaboration CDC and others partners, a similar program was initiated in Chile, Colombia, and Cuba. The approach prioritized hypertension control and secondary prevention, with the ultimate goal of reducing the CVD burden. Key elements of the GSHTP approach have now been included in Global HEARTS, an international initiative for cardiovascular disease that is led by $\mathrm{WHO}$, working in collaboration with other partners.

\section{CURRENT CHALLENGES AND GAPS WITH HYPERTENSION IN LATIN AMERICA AND THE CARIBBEAN}

It is crucial to understand why some national and regional strategies used in LAC for hypertension control have not worked, even where evidence-based clinical guidelines, treatments, and drug availability-or a combination of them-were employed. As in other LMICs globally (9), in the LAC region, health care performance and access and affordability of hypertension drugs varies from country to country. In addition, regulation regarding pricing is often lacking, leaving implementation of hypertension control initiatives still a major challenge. There is also a need to strengthen links between national health care systems and the community, including patients, their families, and community-based organizations working on hypertension control.

Recognizing the gaps inherent in managing NCDs is also an important challenge for the LAC region. PAHO has adopted and is promoting the well-known Chronic Care Model (CCM), an innovative, comprehensive model of care $(19,20)$. The CCM encourages patients in the self-management of their condition, by improving their skills. This requires involving a broad team, as well as coordination and task shifting. Among its components are linkages with community care organizations, resources, and policies; tools for decision support; and clinical information systems to monitor patient progress and clinical performance of the health care organizations. The ultimate goal is to achieve a productive interaction between patients and the health care team (Figure 1) (19). At the same time, PAHO envisions late-stage (T4) translation research helping determine optimal and sustainable strategies to deliver this model.

One crucial gap is the need for better research methods. This includes both mixed methods research designs and multilevel, multidimensional interventions promoted by late-stage (T4) translation research. PAHO recognizes the critical need to enhance the knowledge and skills required for late-stage (T4) translation research. Additional gaps include: 1) understanding how to improve access and quality of clinical care and 2) enhancing medication uptake while strengthening the functioning of primary health care systems. Late-stage (T4) translation research outputs will provide a better understanding of the sustainability and the costs of current and future interventions, which are all recognized as being highly important by WHO, PAHO, and LAC ministries of health.

\section{OPPORTUNITIES FOR LATE-STAGE (T4) TRANSLATION RESEARCH TO ADDRESS HYPERTENSION TREATMENT AND CONTROL IN LATIN AMERICA AND THE CARIBBEAN}

Several LAC countries are currently developing comprehensive NCD control plans for cardiovascular diseases, diabetes, chronic respiratory diseases, and cancer, as well as their respective risk factors. As noted

\section{FIGURE 1. The Chronic Care Model}

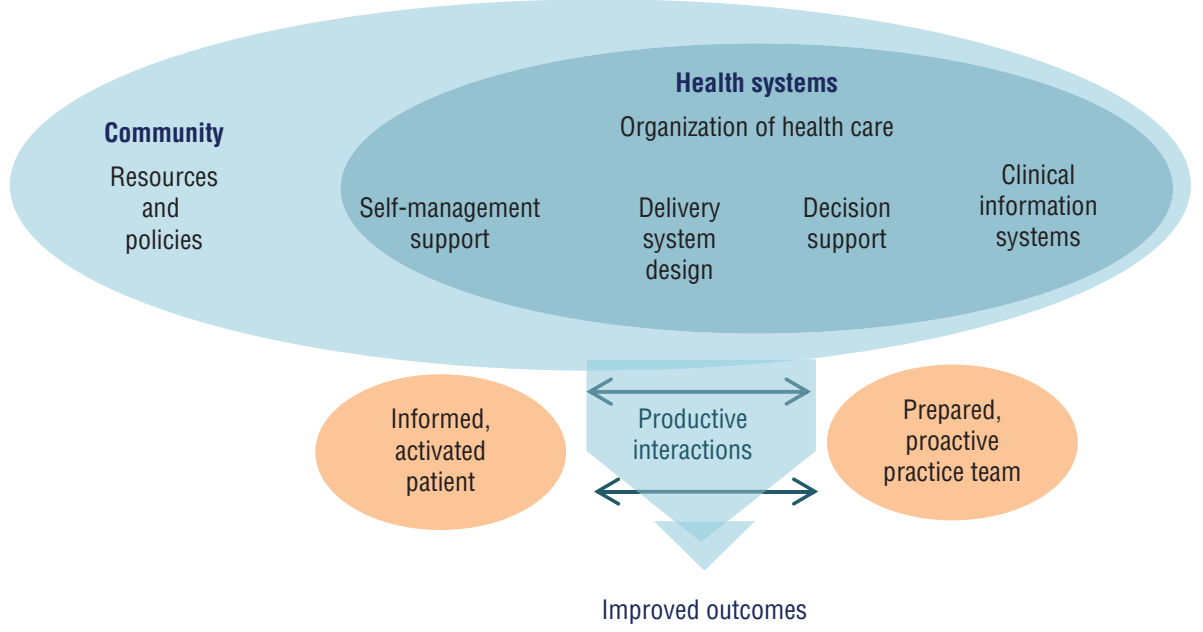

Source: Pan American Health Organization (19). 
above, PAHO is working on implementing a comprehensive plan of action for the period 2013-2019 within the PAHO Strategy for the Prevention and Control of Noncommunicable Diseases. Specific Objective 3.3 of that Strategy focuses on the implementation of effective, evidence-based, and cost-effective interventions for the treatment and control of CVDs, hypertension, diabetes, cancers, and chronic respiratory diseases. This offers an opportunity to utilize late-stage (T4) translation research to determine the best strategies to deliver hypertension control within national and regional plans. Currently, such research is not necessarily incorporated in the decision-making process regarding hypertension control. Changing this could contribute to more cost-efficient and appropriate hypertension control approaches and practices.

Improved utilization of evidence-based interventions-which could be achieved through late-stage (T4) translation research-offers a distinctive opportunity for various stakeholders to work together on hypertension control in the LAC region. The key partners in the research include government agencies, $\mathrm{PAHO}$, universities, research centers, nongovernmental organizations (NGOs), and health care organizations, as well as patients, their families, and other key actors in the health system.

There are already efficient collaborations in some LAC countries, but more comprehensive and integrated ones are needed. These types of partnerships could help in the control of hypertension by building required capacity and by leveraging resources for joint technical and financial assistance.

\section{CONCLUSIONS}

Achieving hypertension control by addressing some of the major current gaps in the LAC region through public health interventions is challenging. It will require the engagement of all stakeholders, as well as the implementation of partnerships and strategic alliances. Efforts will be needed that target patient and health care provider awareness; appropriate lifestyle modifications; access to evidence-based treatment; high levels of medication availability, quality, and adherence; and adequate follow-up.

Late-stage (T4) translation research offers an excellent opportunity for contextualized chronic care models focusing on the major gaps pertaining to delivery of hypertension treatment and control. Moreover, late-stage (T4) translation research represents an opportunity to enhance much-needed public health interventions and concretely identify the optimal, affordable, sustainable delivery strategies needed for hypertension treatment and control both in individual countries and the entire LAC region.

Acknowledgments. We appreciate Daniel Leventhal's assistance on data searching for the initial drafts of this article.

Conflicts of Interest. None declared.
Disclaimer. Authors hold sole responsibility for the views expressed in the manuscript, which do not necessarily represent the views or policy of the Pan American Health Organization; the RPSP/PAJPH; the National Heart, Lung, and Blood Institute; the National Cancer Institute; the National Institutes of Health; the U.S. Department of Health and Human Services; or the U.S. Government.

\section{REFERENCES}

1. World Health Organization. Global status report on noncommunicable diseases 2014. Geneva: WHO; 2014.

2. Gaziano T, Srinath Reddy K, Paccaud F, Horton S, Chaturvedi V. Cardiovascular disease. In: Jamison DT, Breman JG, Measham AR, Alleyne G, Claeson M, Evans $\mathrm{DB}$, et al., eds. Disease control priorities in developing countries. 2nd edition. Washington, D.C.: The International Bank for Reconstruction and Development/ The World Bank; 2006:645-62.

3. Bovet P, Paccaud F. Cardiovascular disease and the changing face of global public health: a focus on low and middle income countries. Public Health Rev. 2012;397-415.

4. Arima H, Barzi F, Chalmers J. Mortality patterns in hypertension. J Hypertens. 2011 Dec;29 Suppl 1:S3-7.

5. Go AS, Bauman MA, Coleman King SM, Fonarow GC, Lawrence W, Williams KA, et al. An effective approach to high blood pressure control: a science advisory from the American Heart Association, the American College of Cardiology, and the Centers for Disease Control and Prevention. Hypertension. 2014 Apr;63(4):878-85. doi: 10.1161/HYP.0000000000000003. Epub 2013 Nov 15.

6. Pan American Health Organization. Health in the Americas. Edition 2017. Washington, D.C.: PAHO; 2017.

7. Ordunez P, Prieto-Lara E, Pinheiro Gawryszewski V, Hennis AJ, Cooper RS. Premature mortality from cardiovascular disease in the Americas - Will the goal of a decline of " $25 \%$ by 2025 " be met? PLoS One. 2015 Oct 29;10(10):e0141685. doi: 10.1371/journal.pone.0141685.

8. Frieden TR, Bloomberg MR. Saving an additional 100 million lives. Lancet. 2017 Sep 12. pii: S0140-6736(17)32443-1. doi: 10.1016/S0140-6736(17)32443-1.

9. Engelgau MM, Peprah E, Sampson UK, Mensah GA. A global health strategy to capitalize on proven-effective interventions for heart, lung, and blood diseases. Glob Heart. 2015 Mar;10(1):87-91. doi: 10.1016/j.gheart. 2015.02.001.

10. Pan American Health Organization. Strategy for the prevention and control of noncommunicable diseases. (Document CSP28/9, Rev. 1). Available from: http://new. paho.org/hq/index.php?option=com_docman\&task=doc _download\&gid $=18607 \& I t e m i d=270 \& l a n g=e n \quad$ Accessed on 19 December 2017.

11. Pan American Health Organization. Plan of Action for the Prevention and Control of Noncommunicable Diseases in the Americas 2013-2019. Washington, D.C.: PAHO; 2014.

12. World Health Organization. Global action plan for the prevention and control of noncommunicable diseases 2013-2020. Geneva: WHO; 2013. (Updated Revised Draft, version dated 15 March 2013). Available from: http:// www.who.int / cardiovascular_diseases / 15March2013UpdatedRevisedDraftActionPlanAPPROVEDBYADG.pdf Accessed on 19 December 2017.

13. Legetic B, Campbell N. Reducing salt intake in the Americas: Pan American Health Organization actions. J Health Commun. 2011;16 Suppl 2:37-48. doi:10.1080/1081 0730.2011 .60122$.

14. Campbell N, Legowski B, Legetic B, Ferrante D, Nilson E, Campbell $\mathrm{C}$, et al. Targets and timelines for reducing salt in processed food in the Americas. J Clin Hypertens (Greenwich). 2014 Sep; 16(9):619-23. doi: 10.1111/ jch.12379. Epub 2014 Jul 31. 
15. Hospedales JC, Barcelo A, Luciani S, Legetic B, Ordunez P, Blanco A. NCD prevention and control in Latin America and the Caribbean. A regional approach to policy and program development. Glob Heart. 2012(7):73-81.

16. Ordunez P, Mize V, Barbosa M, Legetic B, Hennis AJ. A rapid assessment study on the implementation of a core set of interventions to improve cardiovascular health in Latin America and the Caribbean. Glob Heart. 2015(10): 235-40.

17. Patel P, Ordunez P, DiPette D, Escobar MC, Hassell T, Wyss F, et al. Improved blood pressure control to reduce cardiovascular disease morbidity and mortality: the Standardized Hypertension Treatment and Prevention Project. J Clin Hypertens (Greenwich). 2016 Dec; 18(12):1284-94. doi: 10.1111/jch.12861. Epub 2016 Jul 4.

18. Ordunez P, Luciani S, Barojas A, Fitzgerald J, Hennis AJM. A public health approach to hypertension. Lancet.
2015 May 9;385(9980):1833. doi: 10.1016/S0140-6736 (15)60924-2.

19. Pan American Health Organization. Innovative care for chronic conditions: organizing and delivering high quality care for chronic noncommunicable diseases in the Americas. Washington, D.C.: PAHO; 2013.

20. Wagner EH. Chronic disease management: what will it take to improve care for chronic illness? Eff Clin Pract. 1998 (1):2-4.

Manuscript received on 13 June 2017. Revised version accepted for publication on 7 November 2017.

RESUMEN El presente trabajo tuvo dos objetivos: 1) establecer la magnitud del problema y las brechas en cuanto al control de la hipertensión en América

Control de la hipertensión en América Latina y el Caribe: Oportunidades en la última fase (T4) de la investigación sobre la traslación de los resultados a productos

Palabras clave Latina y el Caribe, y 2) determinar la posible función de la última fase (T4) de la investigación sobre traslación de los resultados a productos para hacer frente a la carga actual y futura de la hipertensión en la región. Exploramos la magnitud del problema y las oportunidades de usar última fase (T4) de la investigación sobre traslación de los resultados a productos para abordarlo. Analizamos los llamamientos a la acción y las políticas aplicadas en varios países de América Latina y el Caribe, y también en el plano regional. Actualmente, algunos países de América Latina y el Caribe están elaborando planes integrales para controlar las enfermedades no transmisibles. Además, la Organización Panamericana de la Salud (OPS) está trabajando en la ejecución de un plan de acción integral en el marco de su Estrategia para la prevención y el control de las enfermedades no transmisibles. Estos cometidos destacan la necesidad y la relevancia de las intervenciones eficaces, basadas en la evidencia y asequibles para el tratamiento y el control de la hipertensión. En el marco de estos esfuerzos, la última fase (T4) de la investigación sobre traslación de los resultados a productos puede ayudar a determinar las mejores estrategias para las prestaciones relacionadas con el control de la hipertensión. Esta última fase (T4) debe incluir a todos los interesados directos y asociados pertinentes para mejorar y ampliar las intervenciones de salud pública apropiadas, asequibles y sostenibles.

Hipertensión; investigación en medicina traslacional; salud pública; políticas; América Latina; Indias Occidentales. 
RESUMO Este estudo teve dois objetivos: (1) identificar o alcance do problema e as lacunas referentes ao controle da hipertensão na América Latina e no Caribe

\section{Atividades de controle da hipertensão na América Latina e no Caribe: oportunidades de pesquisa translacional de fase $\mathrm{T} 4$}

(ALC) e (2) identificar o papel em potencial da pesquisa translacional de fase T4 para combater a carga atual e futura da hipertensão na região. Foi investigado o alcance do problema e as oportunidades em potencial para usar pesquisa translacional de fase T4 para abordar o problema. Foram analisadas convocações à ação e políticas adotadas em vários países da ALC e ao nível regional. Alguns países da ALC estão em fase de elaboração de planos abrangentes para controlar as doenças não transmissíveis. Além disso, a Organização Pan-Americana da Saúde (OPAS) está trabalhando na implementação de um plano de ação integral como parte da Estratégia da OPAS para Prevenção e Controle de Doenças Não Transmissíveis. Esses esforços destacam a necessidade e a importância de implementar intervenções com base científica que sejam eficazes e acessíveis para tratar e controlar a hipertensão. Para tal, a pesquisa translacional de fase T4 pode contribuir para determinar as melhores estratégias para realizar o controle da hipertensão. Este tipo de pesquisa deve envolver todos os interessados diretos e parceiros relevantes a fim de expandir e aprimorar as intervenções de saúde pública que sejam adequadas, acessíveis e sustentáveis.

Hipertensão; pesquisa médica translacional; saúde pública; políticas; América Latina; Índias Ocidentais. 